\title{
Expression of oil palm (Elaeis guineensis) polyisoprenoids in response to Ganoderma boninense infection
}

\author{
DADANG AFANDI ${ }^{1}$, MOHAMMAD BASYUNI ${ }^{2,3 \vartheta}$, LOLLIE AGUSTINA P. PUTRI ${ }^{4}$, DIANA CHALIL ${ }^{5}$, \\ INDRA SYAHPUTRA ${ }^{6}$ \\ ${ }^{1}$ Graduate School of Agrotechnology, Faculty of Agriculture, Universitas Sumatera Utara. Medan 20155, North Sumatera, Indonesia \\ ${ }^{2}$ Department of Forestry, Faculty of Forestry, Universitas Sumatera Utara. Jl. Tri Dharma Ujung No. 1 Medan, North Sumatera, 20155, Indonesia. \\ Tel./fax.: +62-61-820-1920. "email: m.basyuni@usu.ac.id \\ ${ }^{3}$ Mangrove and Bio-Resources Group, Center of Excellence for Natural Resources Based Technology, Universitas Sumatera Utara. Medan 20155, North \\ Sumatera 20155, Indonesia \\ ${ }^{4}$ Department of Agrotechnology, Faculty of Agriculture, Universitas Sumatera Utara. Medan 20155, North Sumatera, Indonesia \\ ${ }^{5}$ Department of Agribusiness, Faculty of Agriculture, Universitas Sumatera Utara. Medan 20155, North Sumatera, Indonesia \\ ${ }^{6}$ PT. Socfin Indonesia. J1. KL Yos Sudarso No. 106, Medan 20115, North Sumatera, Indonesia
}

Manuscript received: 21 October 2018. Revision accepted: 2 December 2018.

\begin{abstract}
Afandi D, Basyuni M, Putri LAP, Chalil D, Syahputra I. 2019. Expression of oil palm (Elaeis guineensis) polyisoprenoids in response to Ganoderma boninense infection. Biodiversitas 20: 68-76. Currently, oil palm is an important economic crop and has become one of the world's major vegetable oils as well as a potential source of biodiesel. Unfortunately, oil palm plantations in Asia, particularly in Indonesia and Malaysia face the threat of basal stem root diseases caused by Ganoderma sp. Various methods and approaches have been made to select the oil palm that is tolerant to Ganoderma boninense, among others using biochemical selection. This research aimed to analyze polyisoprenoids expressionof oil palm tolerant to G. boninense using two-dimensional thin layer chromatography (2DTLC). The plant material used in this trial weretwo cross-series of genetic materials belonging to PT Socfindo, that were known to have certain levelsof tolerance to G. boninense. The first wasa cross-series of 15 -year-old oil palm in the field, and the secondwasa new cross-series for an early detection in the nursery stage. The results showed that there werediversitiesin the expression of polyisoprenoids between tissues, treatments, and level of tolerance. Polyprenols with a chain length of $\mathrm{C}_{45}-\mathrm{C}_{65}$ and dolichols of $\mathrm{C}_{45}-\mathrm{C}_{55} \mathrm{were}$ detected in the leaf tissue but not found in the root tissue. Polyprenols with a carbon chain length of $\mathrm{C}_{80}-\mathrm{C}_{100}$ occurred in infected palm root tissue but did not in the healthy oil palm. The increase of polyisoprenoid (polyprenol and dolichol) in infected and inoculated root tissues it is presumablydue to the plant biochemical response to the presence of $G$. boninense attack. Cluster analysis demonstrated distinct groups of polyisoprenoid carbon-chains betweenroot and leaf tissues of oil palm mature and seedling. Interestingly, in the absence of $G$. boninense infection, the polyisoprenoid carbon chain pattern in the tolerant oil palm seedlingroot tissue is different from that in the susceptible seedlings. Thus, the polyisoprenoid carbon chain pattern can be considered as a potential biochemical marker for the screening of oil palm tolerance to G. boninense.
\end{abstract}

Keywords: Biochemical marker olichol, Ganoderma, oil palm, polyisoprenoid, polyprenol

\section{INTRODUCTION}

Oil palm is an important economic crop and currently has become one of the world's major vegetable oils as well as a potential source of biodiesel. Indonesia is now the world's number one palm oil producer with 36.5 million metric tons production per yearor nearly $70 \%$ of world palm oil production (USDA 2017). Unfortunately, oil palm plantations in Asia, particularly in Indonesia and Malaysia face the threat of basal stem root (BSR) diseases caused by Ganoderma boninense(Mohammed et al. 2014).The economic losses due to this disease in both countries amount to 500 million USD per year (Hushiarian et al. 2013). In Indonesia, losses incurred from every $1 \%$ of $G$. boninense attacks is about 256 million USD per year (Morel et al. 2016).

The G. boninense control using tolerant plantsis widely studied and developednowadays. Various methods and approaches have been made to select oil palm that is tolerant to $G$. boninense. A number of observation studies of oil palm infected in the field (commercial plantation, progeny trial, parental gardens, seed garden, and specific G. boninense field trial), early screening test in the nursery stage, and selection at biochemical and molecular levelshave been described (de Franqueville et al. 2010; Tee et al. 2013; Muniroh et al. 2014).

Polyisoprenoids are secondary metabolite compounds that play a role in plant defence systems against biotic and abiotic stresses (Bajda 2005; Zhang et al. 2008; Basyuni et al. 2009, 2017a; Baczewska et al. 2014). Two main groups of polyisoprenoids are polyprenols and dolichols that can be distinguished by the presence of an unsaturated (polyprenols) or saturated (dolichols) $\alpha$-isoprene subunit (Chang et al. 2015; Basyuni et al. 2016). Polyprenols typically range in size from $\mathrm{C}_{45}-\mathrm{C}_{60}$ as shorter polyprenols, medium $\left(\mathrm{C}_{65}-\mathrm{C}_{85}\right)$, and longer polyprenols $\left(\mathrm{C}_{90}-\mathrm{C}_{140}\right)$. Dolichol is present in nearly all plant tissues, particularly in the roots (Tateyama et al. 1999; Basyuni et al. 2016, 2017a, b, 2018a), from the shorter $\left(\mathrm{C}_{25}-\mathrm{C}_{40}\right)$, medium-chain $\left(\mathrm{C}_{65}\right.$ $\left.\mathrm{C}_{85}\right)$, and longer chain length $\left(\mathrm{C}_{90}-\mathrm{C}_{140}\right)$. Polyprenolsare 
primarily associated with photosynthetic tissues (Brasher et al. 2015; Basyuni et al. 2016, 2017a,b, 2108a,b). Polyprenols in oil palm leaf tissue occur in $\mathrm{C}_{45}-\mathrm{C}_{65}$ and $\mathrm{C}_{90}$ $\mathrm{C}_{105}$ length chain, while dolicholsoccur in $\mathrm{C}_{85}-\mathrm{C}_{105}$ (Arifiyanto 2017; Basyuni et al. 2018b).

Several studies have been reported that the profile and occurrence of polyisoprenoids can be used as chemotaxonomic markers (Sun et al. 2010; Basyuni et al. 2016, 2017b, 2018b; Arifiyanto et al. 2017). These results provide an opportunity to get more insightinto the effect of the differences of polyisoprenoid expression on the level of resistance of plants to different pathogens. Furthermore, those findings enable us to investigate the polyisoprenoids expression of oil palm that is tolerant to $G$. boninense. In this study, characterization of polyisoprenoid in palm oil plant was classified as tolerant, moderate and susceptible to BSR disease caused by $G$. boninense. The present study therefore aimed to describe differences in the expression of polyisoprenoid in oil palm and its potential as biochemical markers for the selection of oil palm that is resistant or tolerant against $G$. boninense.

\section{MATERIALS AND METHODS}

\section{Plant materials}

The plant material used in this trial weretwo crossseries of genetic material belonging to PT Socfindo, that were knownto have certain levels of resistance to $G$. boninense. The oil palm materials are of tenera, hybrid between dura and pisifera as previously reported (Basyuni et al. 2017c). The first material is a cross-series of 15-yearold oil palm in the field, henceforth referred to as mature palms. The second one is a new cross-series used for early detection in the nursery stage, henceforth referred to as seedlings. Both cross-series consist of three levels of tolerance group, i.e. tolerant, moderate and susceptible. Samplesof mature palmwere collected from healthy and infected palms from each group. Furthermore, samples from $G$. boninense -inoculated and control seedlings (uninoculated)were collected as well. $G$. boninense inoculation was performed at two-months-old seedlings and then collected for sampling at four months of age. Samplings were taken from leaves and roots tissues and in triplicate from three individual oil palms for each growth stage groups (seedlings and mature), levels of tolerance (tolerant, moderate, and susceptible), and fungal treatment (infected and healthy plants). The classification of the tolerance level of those oil palms are based on the index as used in the research of PT Socfindo which has released the first Ganoderma-resistant oil palm variety in Indonesia in 2013 (Breton et al. 2009).

\section{Oil palm infection with $\boldsymbol{G}$. boninense}

Ganoderma boninense culture was obtained from Pathology Laboratory, Socfindo seed Production \& Laboratories (SSPL) of PT Socfindo Medan. Dikaryotic isolate "J" of $G$. boninense used in this research was obtained from a basidiocarp and was previously isolated from Bangun Bandar Estate, North Sumatera, Indonesia in
2007 and characterised as an aggressive isolate by Breton et al. (2006). For oil palm infection in the seedling stage treatment, G. boninense inoculum was prepared according to Breton et al. 2009. The fungal culture was maintained on potato dextrose agar (PDA) in petri dishes in dark conditions. The inoculum source was based on artificial inoculation using Rubber wood blocks (RWBs) as a substrate. The RWB incubation time used in this work was at 12 weeks. The colonized RWB source was inoculated in the 2 month-old-seedling with the distance between the palm and the RWB inoculum at $5 \mathrm{~cm}$ according to the recommendations of Breton et al. (2006).

Meanwhile the G. boninense infection in the mature palm was by natural infection. The planting material are used in this trial was planted in the area with very high $G$. boninense attack previously. Determination of healthy and infected palms based on the symptoms of an identified $G$. boninense attack.

\section{Chemicals}

The dolichol $\left(\mathrm{C}_{90}-\mathrm{C}_{105}\right)$ and polyprenol $\left(\mathrm{C}_{90}-\mathrm{C}_{100}\right)$ standards were used as previously reported (Basyuni et al. 2016, 2017a) to identify the pattern ofpolyisoprenoid alcohol in the plant materials. Silica gel 60 TLC plates and reverse-phase silica RP-18 HPTLC plates were purchased from Merck (Darmstadt, Germany). All of other chemicals and solvents were reagent grade (Merck, Darmstadt, Germany).

\section{Isolation of polyisoprenoid alcohols}

Separation of polyisoprenoids was carried out following to the previously procedure by Sagami et al. (1992); Basyuni et al. (2016, 2017b). The green leaves and roots tissue were incubated at $60^{\circ} \mathrm{C}$ for $24-48 \mathrm{~h}$. The dried tissue was crushed into fine powder using $5 \mathrm{~g}$ of each were submerged in $30 \mathrm{ml}$ of chloroform/methanol (CM 2/1, v/v) solvent and then incubated in a water bath for 2 days. The supernatant was filtered, then dried using a rotary evaporator. The lipid extract of the leaves and roots was saponified at $65{ }^{\circ} \mathrm{C}$ for $24 \mathrm{~h}$ in $86 \%$ ethanol containing $2 \mathrm{M}$ $\mathrm{KOH}$. The non-saponifiable lipids of each tissue were evaporated and re-dissolved in hexane. All the samples extracted (50-100 mg) were developed to each TLC plate.

First-dimension TLC was performed on a silica-gel glass plate $(20 \times 3 \mathrm{~cm})$ with a solvent system of tolueneethyl acetate $(9: 1)$ for 45 minutes as previously reported (Basyuni et al. 2016; 2017d, 2018a). The second-dimension reversed-phase C-18 silica gel HPTLC was carried out with acetone as the solvent for about 30-40 minutes to transfer all compounds that has been separated in the firstdimension into concentration zone of the reverse-phase TLC plate. To determine the family of a compound and its concentration, dolichols or polyprenols standards were added to the sample line and developed with a solvent system as previously termed (Basyuni et al. 2016). The position of polyisoprenoid alcohol spots that had been developed using 2D-TLC were identified and visualized using iodine vapor. The chromatographic images were obtained and digitally scanned with an Epson perfection V33 series. The polyisoprenoid families pattern were 
determined by comparing the standard of dolichol or/and polyprenol with the occurrence of polyisoprenoid pattern in TLC samples plate. The quantification of polyisoprenoid content in samples was carried out by comparing with dolichol and polyprenol standards. The amount of polyprenols and dolichols that were detected on RP-18 HPTLC glass plates were quanti-fied using ImageJ $1.46 \mathrm{r}$ (Schneider et al. 2012), with dolichol and polyprenol standards as references.

\section{Cluster analysis}

Cluster analysis was carried out on selected subsets of all parameter data comprising of 23 variables, together with polyprenols and dolichols from 32 treatments. The datawere $\log$ (10) transformed as previously reported (Basyuni et al. 2018b). Cluster analysis also was performed on each treatment to grouping the oil palm tolerance. From these data, dendrograms representing all parameter were drawn by clustering analysis using the un-weighted-pair group method with arithmetic mean (UPGMA) in MVSP (multivariate statistical package) 3.22 software (Kovach Computing Service). Euclidean distance was chosen as the criterion for cluster combination.

\section{Statistical analysis}

The data were analyzed by one-wayanalysis of variance (ANOVA) followed by Duncan test forcomparisons of all treatments against the control. The value of $P<0.05$ wasselected as the threshold ofstatistical significance was carried out using the SPSP version 17 statistical software program.

\section{RESULTS AND DISCUSSION}

\section{Total lipid content and polyisoprenoid distribution}

The identification of oil palm toleranceto $G$. boninense wasperformed by $2 \mathrm{D}-\mathrm{TLC}$ to discrete the polyisoprenoids intopolyprenol and dolichol families with different chainlengths. The summaries of the analytical results of thedistribution of polyisoprenoids in each treatment of oil palm tolerance are given inTable 1 .

The weight of total lipid in leaf was higher than in root ofthe mature and the seedling stage. The weight of total lipid within leaves and roots tissueofthe seedlings was higher than that of the mature palm ranging from 55.1 to $73.7 \mathrm{mgg}^{-1} \mathrm{dw}$ (dry weight) and from 38.0 to $45.8 \mathrm{mgg}^{-1}$, respectively. Total lipid content in leaves and roots tissue of mature palm ranges from 32.0 to $43.2 \mathrm{mgg}^{-1} \mathrm{dw}$ and from 4.9 to $8.4 \mathrm{mgg}^{-1} \mathrm{dw}$ respectively. There was no difference in lipids concentration between the tolerant and susceptible palms, but the total lipids content in seedlings treated with Ganoderma was lower than that of the untreated one (not inoculated) (Figure 1 and 2). Furthermore, the total lipid in the root tissue of mature palms infected with Ganoderma was higher than that of thehealthy palms.

The distribution of polyprenols and dolichols in the plant tissue were classified into three types as previously reported (Basyuni et al. 2016, 2017a). In type-I distribution, dolichol predominatesover polyprenol (more than 90\%); type-II displays a comparable occurrence of both polyprenol and dolichol; type III, polyprenol predominates over dolichol by more than $90 \%$. We found that both polyprenol and dolichol in the the plant tissues were on a level with each other or a type II-distribution (Table 1), except or that in the root tissue of the healthy palm and the un-inoculated one which showed a type-I distribution. The Type-II lipid distribution pattern in oil palm leaves tissue found in this study is in accordance with previous reports (Arifiyanto et al. 2017; Basyuni et al. 2018b).

A type-I lipid distribution pattern is found in healthy palm root tissues in which dolichols constitute $100 \%$ of the lipid content. The percentage of polyisoprenoid (especially polyprenol) of the total lipid in all tissues is higher ininfected palms and inoculated seedlingcompared with that of the non-treated palms. High polyprenol content $(2.5$ times) has been also reported on tobacco plant leaves inoculated with tobacco mosaic virus (TMV) (Bajda et al. 2009). This result reinforces the idea of polyisoprenoid involvement in plant resistance to pathogens.

Polyprenol is commonly found in thephotosynthetic plant tissues (Strzalka et al. 2009; Basyuni et al. 2016). Akhtar et al. (2017) reported impaired efficiency of photosystem II in plants lacking polyprenol. Another possible mechanism ofpolyisoprenoidsin protecting biological membranes is by shielding of other lipids and integral membrane proteins (Bajda et al. 2009). Upon an external pathogen attack ( $G$. boninense), the plants responded by synthesizing more polyprenols or dolichols as sugar carriersin the biosynthesis of cellulose and hemicellulose (Zhang et al. 2008; Guam and Eicher 2011), which are components of cell wall damaged by $G$. boninense attack. Several reports have suggested that volatile isoprenoids confer additionalplant protection via cooperation with carotene and tocopherols as antioxidant or serve as alternative defense system when the former mechanism is not sufficient in quenching oxidative stress (Penuelas and Munne-Bosch 2005). In this context, the increased polyprenols in infectedpalms may be a plant response to maintain normal metabolic system.

The polyisoprenoid in leaf tissue is higher than in root tissue, especially the polyprenol content. Different polyprenols expression between plant tissues have been reported in Coluria geoides (Skorupińska-Tudek et al. 2003), Philesia magellanica, Fuchsia magellanica (Strzalka et al. 2009), mangrove plants (Basyuni et al. 2016, 2017a, b), coastal plants (Basyuni et al. 2018a), rambutan (Basyuni and Wati 2017) and oil palm (Arifiyanto et al. 2017; Basyuni et al. 2018b). It is note worthy that polyprenols and dolicholslevel in leaves tissue of matureplant washigher than that of the seedlings. Increased polyprenol in leaves with increasing age has alsobeen reported in Kandelia obovataand Bruguiera gymnorrhiza yellow leaf (Basyuni et al. 2016), old leaves of ginkgo (Tateyama et al. 1999), old rubber leaf (Tateyama et al. 1999) and senescing leaves (Swiezewska et al. 1994). 
Table 1. Distribution of polyprenol and dolichol in oil palm matures and seedlingstolerance to Ganoderma boninense

\begin{tabular}{|c|c|c|c|c|c|c|c|c|c|c|c|c|}
\hline \multirow{2}{*}{ Stage } & \multirow{2}{*}{ Tissue } & \multirow{2}{*}{ Level } & \multirow{2}{*}{ Treatment } & \multirow{2}{*}{$\begin{array}{c}\text { TL } \\
(\mathrm{mg} / \mathrm{g} \mathrm{dw})\end{array}$} & \multirow{2}{*}{$\begin{array}{c}\text { PI } \\
(\mathrm{mg} / \mathrm{g} \text { dw })\end{array}$} & \multirow{2}{*}{$\begin{array}{c}\text { Pol } \\
(\mathrm{mg} / \mathrm{g})\end{array}$} & \multirow{2}{*}{$\begin{array}{c}\text { Dol } \\
(\mathrm{mg} / \mathrm{g})\end{array}$} & \multicolumn{3}{|c|}{$\%$ in $\mathrm{TL}$} & \multicolumn{2}{|c|}{$\%$ in PI } \\
\hline & & & & & & & & PI & Pol & Dol & Pol & Dol \\
\hline Mature & Leaf & Tolerant & Infected & $37.2+5.3$ & 4.0 & 2.4 & 1.5 & 10.7 & 6.6 & 4.2 & 61.2 & 38.8 \\
\hline Mature & Leaf & Tolerant & Healthy & $37.7 \pm 2.0$ & 3.4 & 2.1 & 1.3 & 9.0 & 5.5 & 3.5 & 61.3 & 38.7 \\
\hline Mature & Leaf & Susceptible & Infected & $33.7 \pm 4.9$ & 3.7 & 2.6 & 1.2 & 11.1 & 7.7 & 3.4 & 69.2 & 30.8 \\
\hline Mature & Leaf & Susceptible & Healthy & $38.8 \pm 5.2$ & 7.0 & 5.0 & 2.0 & 18.1 & 12.8 & 5.3 & 70.8 & 29.2 \\
\hline Mature & Leaf & Moderate & Infected & $36.8 \pm 2.7$ & 6.8 & 4.7 & 2.2 & 18.6 & 12.7 & 5.9 & 68.4 & 31.6 \\
\hline Mature & Leaf & Moderate & Healthy & $32.0 \pm 4.3$ & 2.8 & 1.9 & 0.9 & 8.8 & 6.0 & 2.8 & 67.8 & 32.2 \\
\hline Mature & Leaf & Moderate & Infected & $38.7 \pm 5.5$ & 4.7 & 2.7 & 2.1 & 12.3 & 6.9 & 5.3 & 56.6 & 43.4 \\
\hline Mature & Leaf & Moderate & Healthy & $43.2 \pm 0.3$ & 5.4 & 2.7 & 2.7 & 12.6 & 6.2 & 6.4 & 49.5 & 50.5 \\
\hline Mature & Root & Tolerant & Infected & $8.4 \pm 1.7$ & 1.4 & 0.6 & 0.7 & 16.4 & 7.7 & 8.7 & 46.8 & 53.2 \\
\hline Mature & Root & Tolerant & Healthy & $4.9 \pm 2.5$ & 0.7 & nd & 0.7 & 14.8 & nd & 14.8 & 0.0 & 100.0 \\
\hline Mature & Root & Susceptible & Infected & $6.6 \pm 0.5$ & 2.6 & 1.2 & 1.4 & 39.3 & 18.7 & 20.6 & 47.5 & 52.5 \\
\hline Mature & Root & Susceptible & Healthy & $6.7 \pm 1.8$ & 1.1 & 0.3 & 0.8 & 16.9 & 4.5 & 12.4 & 26.8 & 73.2 \\
\hline Mature & Root & Moderate & Infected & $5.8 \pm 0.5$ & 0.7 & 0.2 & 0.5 & 12.7 & 3.8 & 8.8 & 30.3 & 69.7 \\
\hline Mature & Root & Moderate & Healthy & $5.8 \pm 2.0$ & 0.6 & nd & 0.6 & 10.8 & nd & 10.8 & 0.0 & 100.0 \\
\hline Mature & Root & Moderate & Infected & $7.5 \pm 0.7$ & 1.8 & 0.7 & 1.1 & 23.9 & 9.7 & 14.2 & 40.6 & 59.4 \\
\hline Mature & Root & Moderate & Healthy & $7.7 \pm 1.8$ & 0.6 & nd & 0.6 & 7.8 & $\mathrm{Nd}$ & 7.8 & 0.0 & 100.0 \\
\hline Seedling & Leaf & Tolerant & Uninoculated & $73.3 \pm 13.1$ & 2.8 & 1.8 & 1.0 & 3.8 & 2.4 & 1.4 & 63.5 & 36.5 \\
\hline Seedling & Leaf & Tolerant & Inoculated & $55.1 \pm 31.2$ & 2.3 & 1.4 & 0.9 & 4.2 & 2.5 & 1.6 & 61.3 & 38.7 \\
\hline Seedling & Leaf & Susceptible & Uninoculated & $69.8 \pm 25.7$ & 2.6 & 1.6 & 1.0 & 3.7 & 2.3 & 1.4 & 63.0 & 37.0 \\
\hline Seedling & Leaf & Susceptible & Inoculated & $62.5 \pm 23.8$ & 3.0 & 2.0 & 0.9 & 4.7 & 3.2 & 1.5 & 68.0 & 32.0 \\
\hline Seedling & Leaf & Moderate & Uninoculated & $67.3 \pm 16.8$ & 2.1 & 1.2 & 0.8 & 3.1 & 1.9 & 1.2 & 59.9 & 40.1 \\
\hline Seedling & Leaf & Moderate & Inoculated & $65.2 \pm 13.4$ & 3.0 & 1.9 & 1.1 & 4.5 & 2.9 & 1.6 & 63.8 & 36.2 \\
\hline Seedling & Leaf & Tolerant & Uninoculated & $43.8 \pm 16.5$ & 1.0 & 0.7 & 0.3 & 2.4 & 1.6 & 0.7 & 69.4 & 30.6 \\
\hline Seedling & Leaf & Tolerant & Inoculated & $43.6 \pm 12.1$ & 1.2 & 0.8 & 0.4 & 2.9 & 1.9 & 1.0 & 65.1 & 34.9 \\
\hline Seedling & Root & Susceptible & Uninoculated & $45.8 \pm 25.4$ & 0.3 & 0.3 & nd & 0.6 & 0.6 & nd & 100.0 & 0.0 \\
\hline Seedling & Root & Susceptible & Inoculated & $41.9 \pm 13.5$ & 1.0 & 0.7 & 0.4 & 2.5 & 1.6 & 0.9 & 62.5 & 37.5 \\
\hline Seedling & Root & Moderate & Uninoculated & $39.4 \pm 13.2$ & 1.0 & 0.6 & 0.4 & 2.6 & 1.5 & 1.1 & 56.9 & 43.1 \\
\hline Seedling & Root & Moderate & Inoculated & $38.0 \pm 15.0$ & 1.7 & 0.9 & 0.8 & 4.5 & 2.5 & 2.1 & 54.5 & 45.5 \\
\hline
\end{tabular}

Note: Total lipids are represented as the mean \pm SD $(n=3)$, TL: total lipid, PI: polyisoprenoids, Pol: polyprenol, Dol: dolichol, nd: not detected
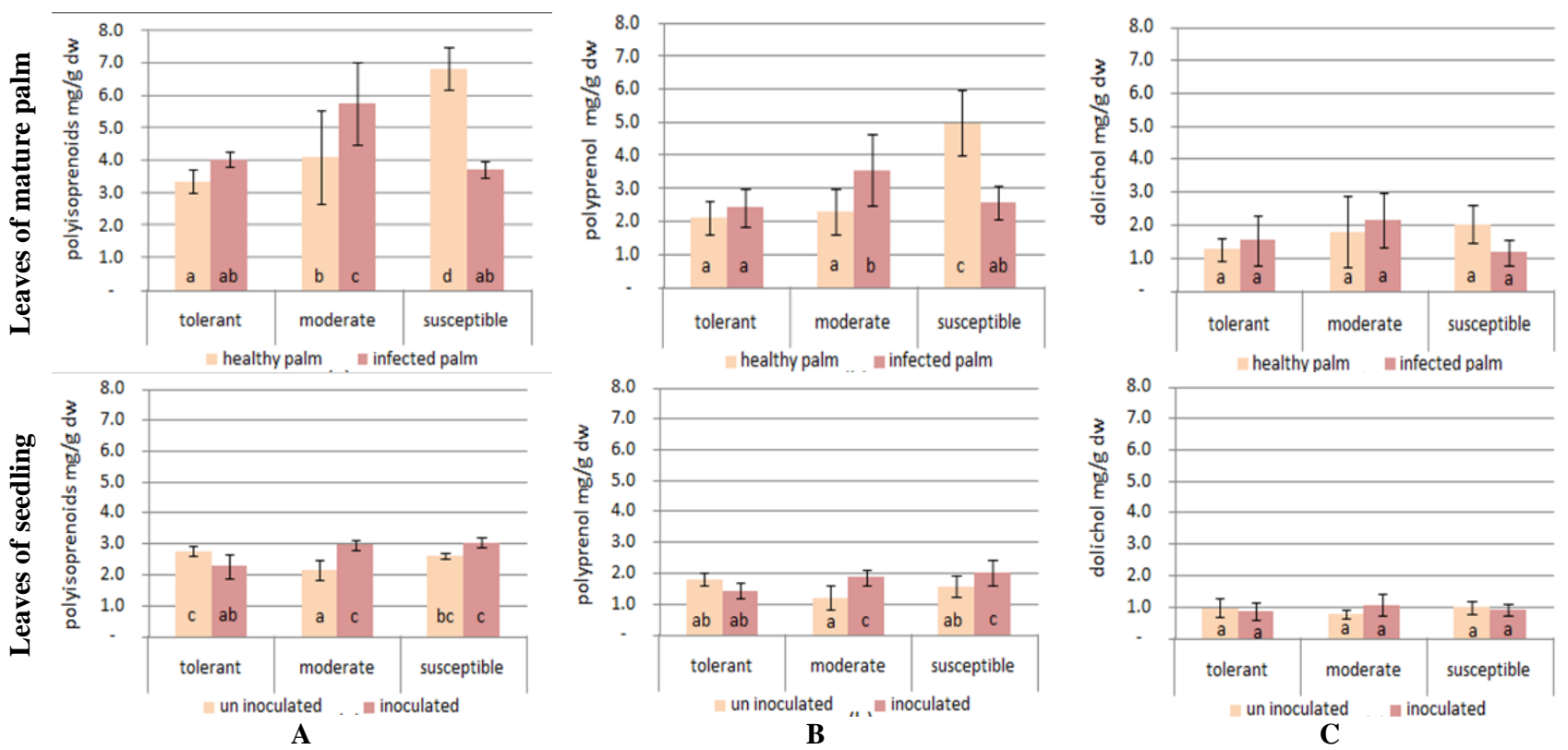

Figure 1. Content of polyisoprenoids (A), polyprenol (B), and dolichol (C) of oil palm leaves tissue. Data are represented as the mean \pm $\mathrm{SD}(n=3)$. Different letter showing statistically significant differences $P<0.05$ by Duncan test 
Table 2. Carbon-chain length of polyprenol and dolichol in oil palm tolerance to Ganoderma boninense

\begin{tabular}{|c|c|c|c|c|c|}
\hline Stage & Tissue & Level & Treatment & Polyprenol* & Dolichol* \\
\hline$\overline{\text { Mature }}$ & Leaf & Tolerant & Infected & $4550556065 \ldots \ldots \ldots 80859095$ & .80859095100 \\
\hline Mature & Leaf & Tolerant & Healthy & $45505560 \ldots \ldots \ldots \ldots \ldots . .8590$ & $5055 \ldots \ldots \ldots 80859095100$ \\
\hline Mature & Leaf & Susceptible & Infected & $4550556065 \ldots \ldots \ldots 80859095$ & .80859095100 \\
\hline Mature & Leaf & Susceptible & Healthy & $4550556065 \ldots \ldots \ldots \ldots .859095$ & .80859095100 \\
\hline Mature & Leaf & Moderate & Infected & $4550556065 \quad \ldots \ldots \ldots \ldots \ldots 9095$ & ...80859095 100 \\
\hline Mature & Leaf & Moderate & Healthy & $\mathbf{5 0} 556065 \ldots \ldots \ldots \ldots . \ldots 9095$ & ..80 859095 \\
\hline Mature & Leaf & Moderate & Infected & $4550556065 \ldots \ldots \ldots 80859095100$ & $5055 \ldots \ldots \ldots 80859095100105$ \\
\hline Mature & Leaf & Moderate & Healthy & $4550556065 \ldots \ldots \ldots 80859095$ & $505560 \ldots \ldots 80859095100$ \\
\hline Mature & Root & Tolerant & Infected & ....8080859095100 & ...7580859095 100105 \\
\hline Mature & Root & Tolerant & Healthy & nd & $\ldots 80859095100$ \\
\hline Mature & Root & Susceptible & Infected & ....80859095100 & .7580859095100 \\
\hline Mature & Root & Susceptible & Healthy & nd & $\ldots 80859095$ \\
\hline Mature & Root & Moderate & Infected & ...9095100 & $\ldots 80859095100$ \\
\hline Mature & Root & Moderate & Healthy & nd & $\ldots 80859095100$ \\
\hline Mature & Root & Moderate & Infected & ........859595 100 & .7580859095100105 \\
\hline Mature & Root & Moderate & Healthy & nd & ...80 859095100 \\
\hline Seedling & Leaf & Tolerant & Uninoculated & .......859095100 & ....80859095100 \\
\hline Seedling & Leaf & Tolerant & Inoculated & .......859095100 & ...880859095100 \\
\hline Seedling & Leaf & Susceptible & Uninoculated & ...88859095 & .7580859095 \\
\hline Seedling & Leaf & Susceptible & Inoculated & ...80859095 & . . ...80859095100 \\
\hline Seedling & Leaf & Moderate & Uninoculated & ........859095100 & . . . .80859095100 \\
\hline Seedling & Leaf & Moderate & Inoculated & $45505560 \ldots \ldots \ldots \ldots \ldots . . . .859095100$ & ........859095 100 \\
\hline Seedling & Leaf & Moderate & Uninoculated & $45505560 \ldots \ldots \ldots \ldots 80859095$ & .......859595 \\
\hline Seedling & Leaf & Moderate & Inoculated & $45505560 \ldots \ldots \ldots \ldots$ & $\ldots \ldots . . .859095$ \\
\hline Seedling & Root & Tolerant & Uninoculated & $\mathbf{6 5} 70 \ldots \ldots \ldots \ldots 9095$ & ...808590 \\
\hline Seedling & Root & Tolerant & Inoculated & $6570 \ldots$ & $\ldots 808590$ \\
\hline Seedling & Root & Susceptible & Uninoculated & .9095 & nd \\
\hline Seedling & Root & Susceptible & Inoculated & 6570 & ..880859095 \\
\hline Seedling & Root & Moderate & Uninoculated & .9095 & ...808590 \\
\hline Seedling & Root & Moderate & Inoculated &. .9095100 & ...808590 \\
\hline Seedling & Root & Moderate & Uninoculated & 6570 & nd \\
\hline Seedling & Root & Moderate & Inoculated & 6570 & nd \\
\hline
\end{tabular}

Note: *The numbers refer to the carbon-chain length of the polyisoprenoid alcohols. The chain length of the primary polyisoprenoidalcohols in each tissue are indicated in bold. Data are represented as three independent experiments. nd: not detected

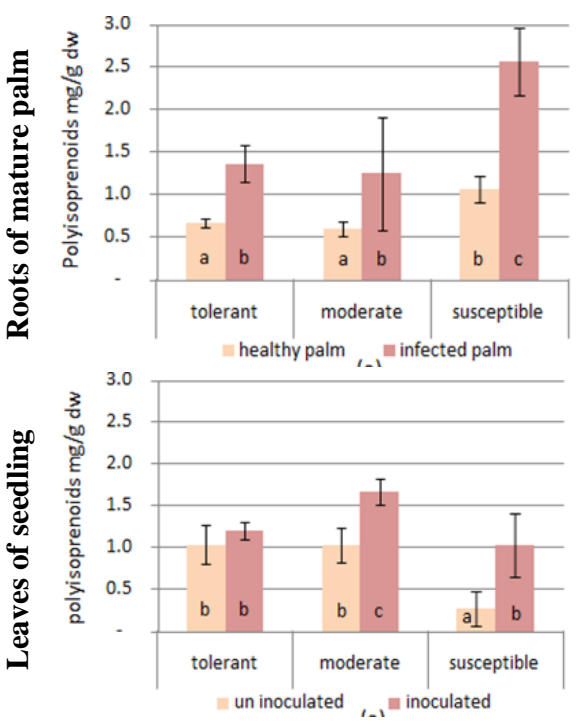

A
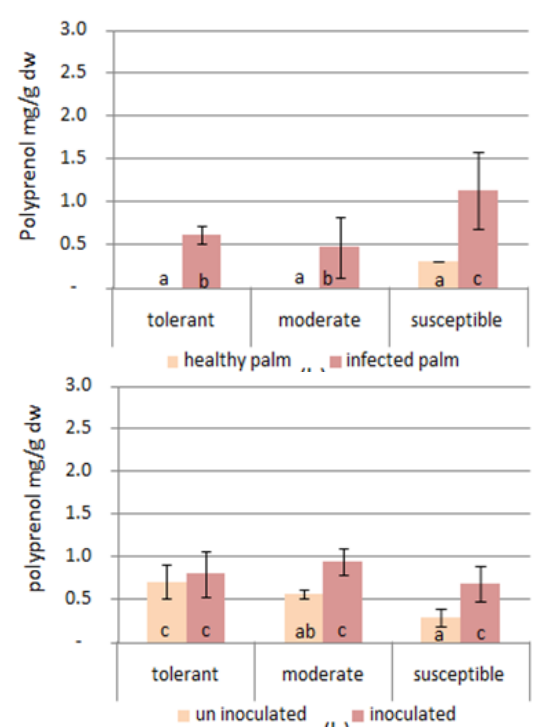

B

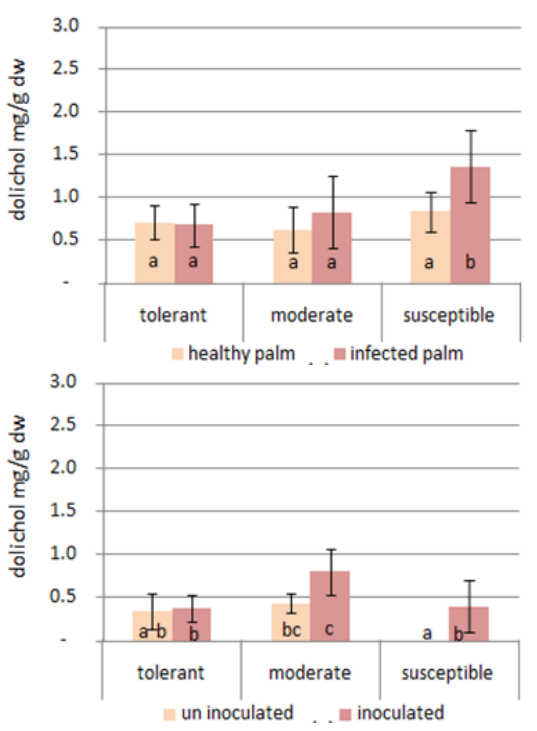

C

Figure 2. The content of Polyisoprenoids (A), polyprenol (B), and dolichol (C) of oil palm root tissue.Data are represented as the mean $\pm \mathrm{SD}(n=3)$. Different letter showing statistically significant differences $P<0.05$ by Duncan test 


\section{Carbon-chain length of polyisoprenoid in oil palm}

The carbon-chain length of polyisoprenoid in oil palm as shown in Table 2 varied according to the sample's growth stages and tissue types,even in the the same species and formed a particular family with dominant molecule species (Tateyama et al. 1999; Basyuni et al. 2016, 2017a,b). Therefore, in this study, the samples collected from plant groups with different tolerance response to $G$. boninense were sorted into same group of ages and growth stages. Thus, the composition of the carbon-chain length in each group was consistent and the differentiation among the tolerance level to $G$. boninensecould be identified.

The carbon-chains of polyprenols and dolichols in mature palm leaves tissue are nearly similar to those in the seedlings leaves (Table2/Figure 2), as was suggested by the previous reports (Arifiyanto et al. 2017; Basyuni et al. $2018 b$ ). Difference in carbon-chain patterns was detected between leaves and root tissue, both in mature and seedling stages (Figures 3 and 4). In the mature palm roots tissue, there is no occurrence of carbon-chain polyprenols $\mathrm{C}_{45^{-}}$ $\mathrm{C}_{65}$ and dolichols $\mathrm{C}_{50}-\mathrm{C}_{55}$ (Figure 3(b)), only carbon chains of polyprenol $\mathrm{C}_{80}-\mathrm{C}_{105}$ and dolichol $\mathrm{C}_{75}-\mathrm{C}_{105}$ wasobserved (Figure 3(b)). A similar carbon-chain pattern was occurred in mature and seedling leaves tissue. In the roots tissue of seedlings,there is only a short carbon-chain of polyprenols $\mathrm{C}_{65}-\mathrm{C}_{70}$ and $\mathrm{C}_{90}-\mathrm{C}_{95}$ and dolichol $\mathrm{C}_{80}-\mathrm{C}_{90}$ detected (Figures 4 and 5).

Differential carbon-chain patterns between oil palms with different tolerance levels were not explicitly detected in this study. The polyisoprenoid carbon-chain in the tolerant, moderate and susceptible oil palmsshowed inconsistent patterns (Table 2 ). However, we found a contrast polyprenol carbon-chains pattern in root tissues between the infected and uninoculated palms. $\mathrm{C}_{80^{-}}$ $\mathrm{C}_{100}$ polyprenols were detected in the root tissue of the infected palm, but absent in the healthy palm(Figure 5). Furthermore, seedlings inoculated with $G$. boninenseexhibited more complete array of polyprenol carbon-chains in their root tissues compared with the inoculated seedlings (Figure 6).

\section{Cluster analysis of polyisoprenoid data}

The pattern of carbon-chain was analyzed and translated into binary data and visualized into dendrogram using UPGMA method. The dendrogram was expected to group oil palm samples according to levels of tolerance to $G$. boninense. The first dendrogram uses all the samples from all parameters (Figure 7). The samples were clustered into two large groups at the similarity coefficient of 1.02 , i.e., the groups of root and leaf tissues. This result suggests that there aredistinct groups of polyisoprenoid carbonchains pattern in root and leaf tissues of oil palm crops. Further groupings were observed at the similarity coefficient of 0.81 , groups of root tissue, the mature and the seedling. Meanwhile, the grouping between mature and seedling leaves tissue was united at the coefficient of similarity 0.62 .

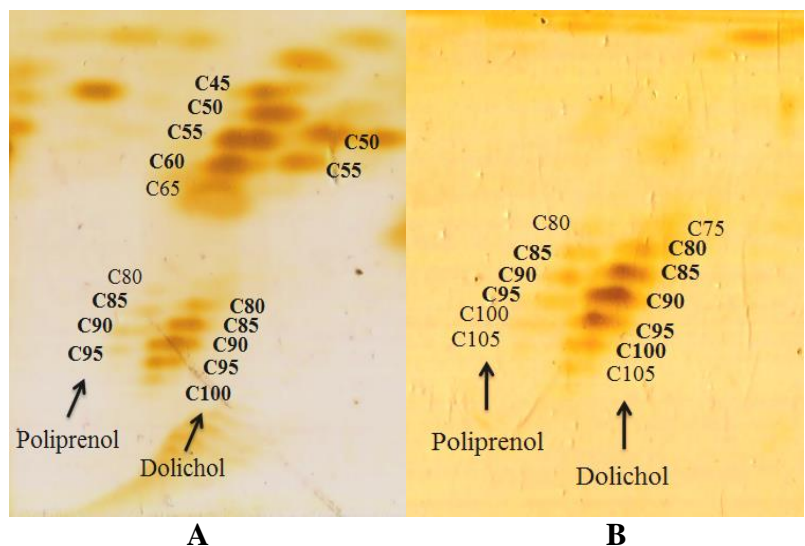

Figure 3. 2D-TLC chromatograms of polyisoprenoids from tolerant oil palm mature in leaves (A) and roots (B) tissue. The Carbon number refers to the carbon-chain length of polyisoprenoid alcohols

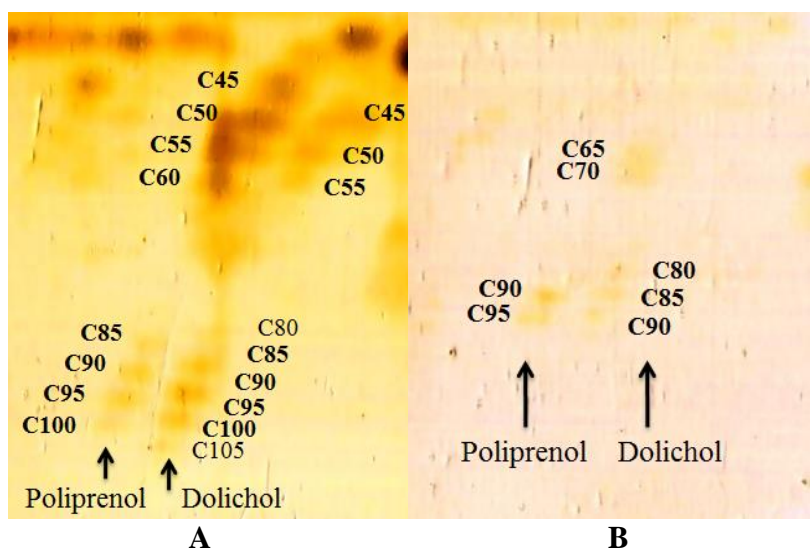

Figure 4. 2D-TLC chromatograms of polyisoprenoids from tolerant oil palm seedling in leaves (A) and roots (B) tissue. The Carbon number refers to the carbon-chain length of polyisoprenoid alcohols

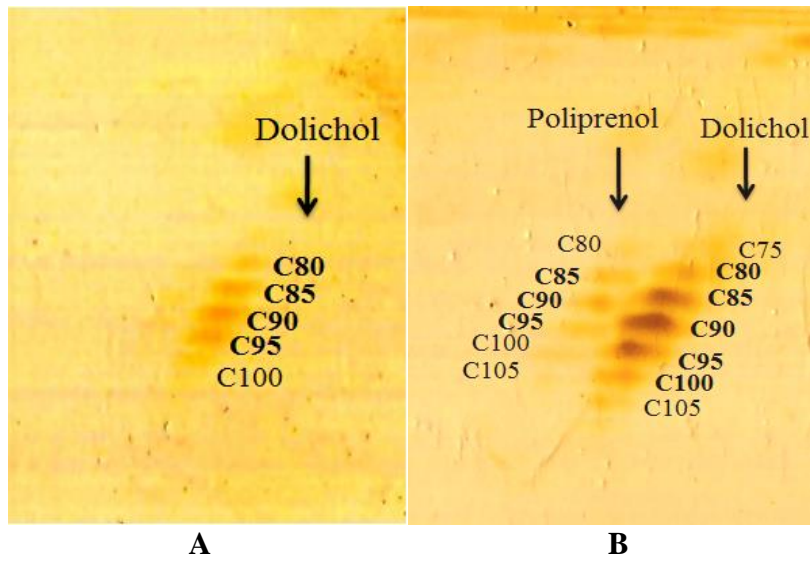

Figure 5. 2D-TLC chromatograms of polyisoprenoids from healthy palm (A) and infected (B) by Ganoderma in tolerant oil palm mature root tissue. The Carbon number refers to the carbonchain length of polyisoprenoid alcohols 


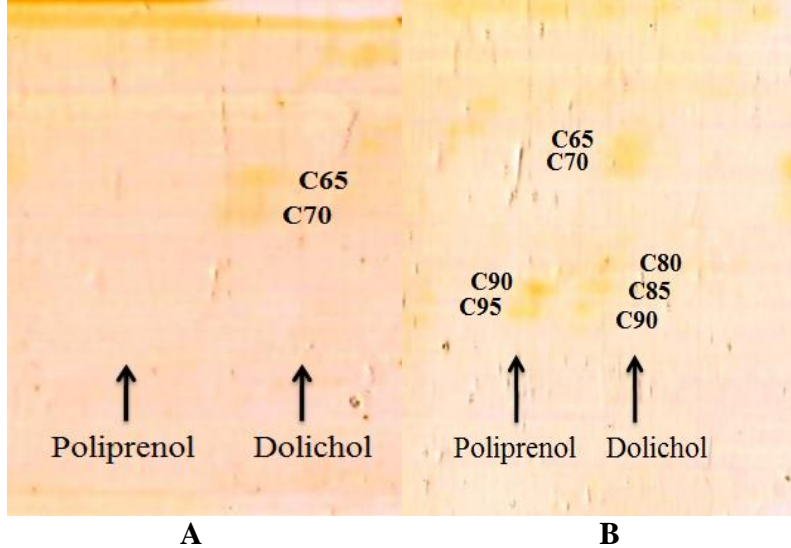

Figure 6. 2D-TLC chromatograms of polyisoprenoids from uninoculated (A) and inoculated (B) with Ganoderma in susceptible oil palm seedling root tissue. The Carbon number refers to the carbon-chain length of polyisoprenoid alcohols

For grouping level of tolerance, cluster analysis was performed based on each parameter. A dendogram was developed by considering different polyisoprenoids carbonchain patterns between treatments, as a response of the plants to the treatment. The dendrogram is a diagram of UPGMA analysis based on polyisoprenoid carbon-chain in root tissue of oil palm seedlings that are not inoculated with G. boninense (Figure 8). The dendogram shows a separation into two groups of tolerance occur at the coefficient of similarity of 0.67 (Figure 8). The first group (Group I) consisted of plants with susceptible to moderate tolerance to G. boninense, and the second (Group II) comprised plants with moderate to tolerant response to $G$. boninense. The moderate plants are populations of individual palms generated from the segregation of susceptible and tolerant plants crossing. Moderate plants in group I may be a tolerant individual that has the same carbon-chain pattern as the tolerant plants or a susceptible plant that has the same carbon-chain pattern of susceptible plants as shown in Figure 8.

In root tissues of tolerant oil palm seedling, the carbonchain of polyprenols and dolichol are $\mathrm{C}_{65}-\mathrm{C}_{70}$ and $\mathrm{C}_{90}-\mathrm{C}_{95}$; and $\mathrm{C}_{80}-\mathrm{C}_{90}$, respectively, while in the susceptible seedlings, there is only one short carbon-chain observed (Table 3). When an external pathogen of $G$. boninense attacked, the plant responded by synthesizing more polyprenol or dolichol as a sugar carrier (Guan and Eicher 2011) in the cellulosic and hemicellulosic biosynthesis processes that are components of the cell wall damaged by G. boninense attack. Therefore, oil palm screening for tolerance toG. boninense with polyisoprenoid biochemical markers should be performed on healthy plants or without treatment of $G$. boninense inoculation. These data support an increase in polyprenol and dolicol in plants infected with pathogen. In un-inoculated seedlings have less polyisoprenoid contents (polyprenol and dolicol), but in inoculated plants (given attack) polyisoprenoid alcohol both polyprenols and dolichols increased. Likewise, in maturestage, infectedplants have higher polyisoprenoids content as a form of defense response to the fungal pathogen attack.

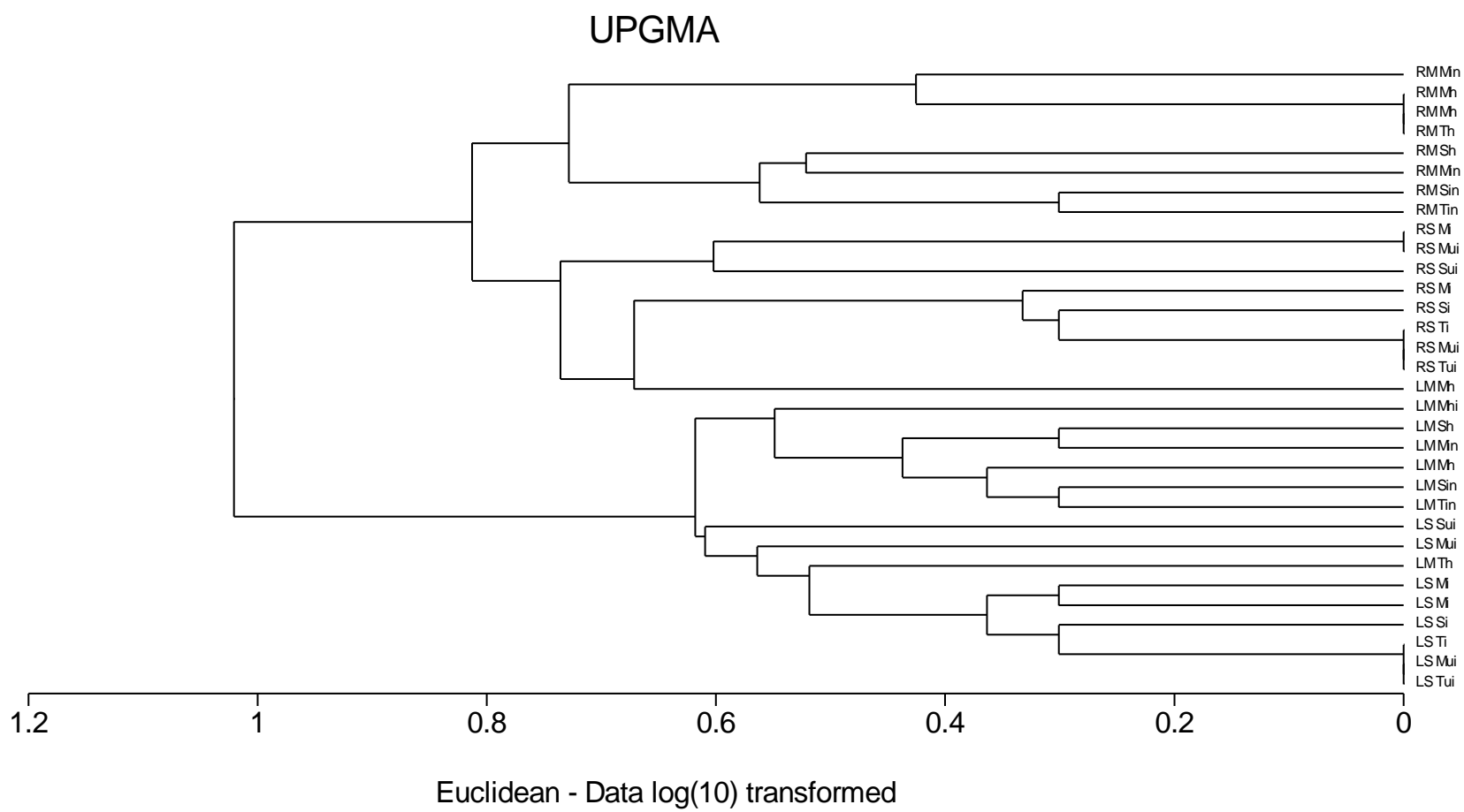

Figure 7. The UPGMA dendrogram is depicting the similarity among 32 oil palm tolerance to Ganoderma from leaves and root tissue based on carbon-chain lengths of polyisoprenoids. R: Root tissue, L: Leaves tissue, M: Mature palm, S: Seedling stage, T: Tolerant, S: Susceptible, M: Moderate, h: Healthy plant, In: Infected, I: Inoculated uI: Un-inoculated 


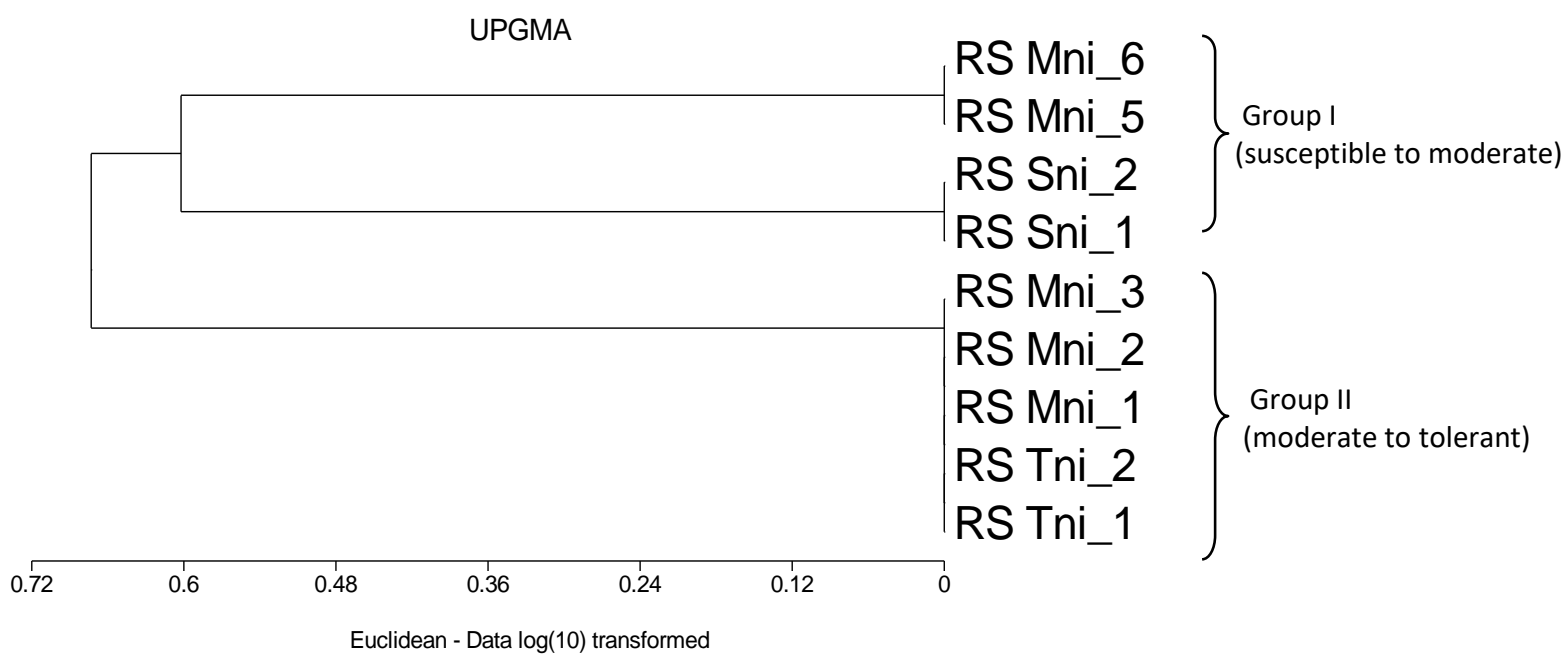

Figure 8. The UPGMA dendrogram depicts the group of oil palm tolerance to Ganoderma in the seedling stage from root tissue based on the carbon-chain lengths of polyisoprenoids. R: Root tissue, S: Seedling stage, Mni: moderate un-inoculated, Tni: tolerant uninoculated, Sni: susceptible un-inoculated, 1, 2 etc: sample number 1, 2 etc.

Table 3. Carbon-chain length of polyprenol and dolichol in root tissues oil palm seedlings infected with $G$. boninense

\begin{tabular}{|c|c|c|c|c|c|}
\hline Treatment & Family of female parent & Family of male parent & Tolerance level & Polyprenol* & Dolichol* \\
\hline $\begin{array}{l}\text { Uninoculated } \\
\text { Seedlings } \\
\text { (healthy) }\end{array}$ & $\begin{array}{ll}\text { SL } & 2980 \\
\text { PO } & 6144 \\
\text { PO } & 6144 \\
\text { SL } & 2980\end{array}$ & $\begin{array}{ll}\text { SL } & 1837 \\
\text { SL } & 2787 \\
\text { SL } & 1837 \\
\text { SL } & 2787\end{array}$ & $\begin{array}{c}\text { Tolerant } \\
\text { Susceptible } \\
\text { Moderate } \\
\text { Moderate }\end{array}$ & $\begin{array}{r}6570 \ldots . . .9995 \\
\ldots . . .9095 \\
6570 \ldots \ldots 9095 \\
6570 \ldots .\end{array}$ & $\begin{array}{l}\ldots 808590 \\
\text { nd } \\
\ldots 808590 \\
\text { nd }\end{array}$ \\
\hline $\begin{array}{l}\text { G. boninense- } \\
\text { infected } \\
\text { seedlings }\end{array}$ & $\begin{array}{ll}\text { SL } & 2980 \\
\text { PO } & 6144 \\
\text { PO } & 6144 \\
\text { SL } & 2980 \\
\end{array}$ & $\begin{array}{ll}\text { SL } & 1837 \\
\text { SL } & 2787 \\
\text { SL } & 1837 \\
\text { SL } & 2787 \\
\end{array}$ & $\begin{array}{l}\text { Tolerant } \\
\text { Susceptible } \\
\text { Moderate } \\
\text { Moderate } \\
\end{array}$ & $\begin{array}{l}6570 \ldots . . .9095 \\
6570 \ldots . . .9095 \\
6570 \ldots \ldots 9095100 \\
6570 \ldots .\end{array}$ & $\begin{array}{l}\ldots 808590 \\
\ldots 808590 \\
\ldots 808590 \\
\text { nd }\end{array}$ \\
\hline
\end{tabular}

Note: *The numbers refer to the carbon-chain length of the polyisoprenoid alcohols. Data are represented as three independent experiments. nd: not detected

In conclusion, polyisoprenoid profiles and polyisoprenoid carbon-chain pattern in the root tissue of the healthy oil palm plants were distinguishable from that of the $G$. boninense-infected oil palm, suggesting a biochemical response of the plant to G. boninense fungal pathogen attack. The difference in the polyisoprenoid carbon-chain pattern in the root of tolerant and susceptible oil palmis a potential biochemical marker for the screening and selection of plants tolerant to G. boninense.

\section{ACKNOWLEDGEMENTS}

This work was supported in part by a Penelitian Strategis Nasional Institusi (PSN Institusi 2018 to MB) from the Directorate for Research and Community Service, Ministry of Research, Technology and Higher Education, Republic of Indonesia. The authors are also grateful to PT. Socfin Indonesia (Socfindo) and Universitas Sumatera Utara.

\section{REFERENCES}

Akhtar TA, Surowiecki P, Siekierska H, Kania M, Van Gelder K, Rea K, Virta L, Vatta M, Gawarecka K, Wojcik J, Danikiewicz W. 2017. Polyprenols are synthesized by a plastidial cis-prenyltransferase and influence photosynthetic performance. Plant Cell 29: 1709-1725.

Arifiyanto D, Basyuni M, Sumardi, Agustina LS, Etti Sartina ES, Risnasari I, Syahputra I. 2017. Ooccurrence and cluster analysis of palm oil (Elaeis guineensis) fruit type using two-dimensional thin layer chromatography. Biodiversitas 18 (4): 1487-1492.

Baczewska AH, Dmuchowski W, Jozwiak A, Gozdowski D, Brągoszewska P, Dąbrowski P, Swiezewska E. 2014. Effect of salt stress on prenol lipids in the leaves of Tilia 'Euchlora'. Dendrobiology 72: 177-186.

Bajda A, Chojnacki T, Hertel J, Swiezewska E, Wójcik J, Kaczkowska A, Marczewski A, Bojarczuk T, Karolewski P, Oleksyn J. 2005. Light conditions alter accumulation of long chain polyprenols in leaves of trees and shrubs throughout the vegetation season. Acta Biochim Pol 52:233-241.

Bajda A, Konopka-Postupolska D, Krzymowska M, Hennig J, Skorupinska-Tudek K, Surmacz L, Wojcik J, Matysiak Z, Chojnacki T, Skorzynska-Polit E, Drazkiewicz M, Patrzylas P, Tomaszewska M, Kania M, Swist M, Danikiewiczc W, Piotrowska W, Swiezewska E. 
2009. Role of polyisoprenoids in tobacco resistance against bioticstresses. Physiol Plant135: 351-364.

Basyuni M, Baba S, Inafuku M, Iwasaki H, Kinjo K, Oku H. 2009. Expression of terpenoid synthase mRNA and terpenoid content in salt-stressed mangrove. J Plant Physiol 166: 1786-1800.

Basyuni M, Sagami H, Baba S, Iwasaki H, Oku H. 2016. Diversity of polyisoprenoids in ten Okinawan mangroves. 2016. Dendrobiology 75: 167-175.

Basyuni M, Sagami H, Baba S, Putri LAP, Wati R, Oku H. 2017a. Salinity alters the polyisoprenoid alcohol content and composition of both salt-secreting and non-salt-secreting mangrove seedlings. HAYATI J Biosci 24: 206-2014.

Basyuni M, Sagami H, Baba S, Iwasaki H, Oku H. 2017b. Distribution, occurrence, and cluster analysis of new polyprenyl acetones and other polyisoprenoids from North Sumatran mangroves. Dendrobiology 78 18-31.

Basyuni M, Amri N, Putri LAP, Syahputra I, Arifiyanto D. 2017c Characterization of fresh bunch yield and the physicochemical qualities of palm oil during storage in North Sumatra, Indonesia. Indones J Chem 18: 182-190.

Basyuni M, Wati R. 2017. Distribution and occurrence of polysioprenoids in rambutan (Nephelium lappaceum). IOP Conf Ser: Earth Environ Sci 101: 012001.

Basyuni M, Wati R, Sagami H, Sumardi, Baba S, Oku H. 2018a. Diversity and abundance of polysioprenoid composition in coastal plant species from North Sumatra, Indonesia. Biodiversitas 19: 1-11.

Basyuni M, Wati R, Deni I, Tia AR, Slamet B, Siregar ES, Syahputra I 2018b. Cluster analysis of polyisoprenoid in oil palm (Elaeis guineensis) leavesin different land-uses to find the possible cause of yield gap from planting materials. Biodiversitas 19: 1492-1501.

Brasher MI, Surmacz L, Leong B, Pitcher J, Swiezewska E, Pichersky E, Akhtar TA. 2015. A two-component enzyme complex is required for dolichol biosynthesis in tomato. Plant J 82: 903-914.

Breton F, Miranti R, Lubis Z, Hayun Z, Setiawati U, Flori A, Nelson S, Durand T, Jacquemard JC, de Franqueville H. 2009. Implementation of an early artificial inoculation test to screen oil palm progenies for their level of resistance and hypothesis on natural infection Ganoderma disease of the oil palm In : 16th International Oil Palm Conference and Expopalma. Challenges in sustainable oil palm development, 22 to 25 September 2005, Cartegena de Indias, Colombia.

Breton F, Hasan Y, Hariadi, Lubis Z, de Franqueville H. 2006 Characterization of parameters for the development of an early screening test for basal stem rot tolerance in oil palm progenies. J Oil Palm Res (Spec):24-36.

Chang MM, Barbara Imperiali B, Eichler J, Ziqiang Guan Z. 2015. Nlinked glycans are assembled on highly reduced dolichol phosphate carriers in the hyperthermophilic Archaea Pyrococcus Furiosus. PLoS ONE. 10(6):e0130482.

de Franqueville H, Asmady H, Jacquemard JC, Hayun Z, Durand-Gasselin T. 2001. Indications on sources of oil palm (Elaeis guineensis Jacq.) genetic resistance and susceptibility to Ganoderma sp., the cause of basal stem rot. In Cutting-Edge Technologies for sustained
Competitiveness, Proceedings of International Palm Oil Congress, Eds Malaysian Palm Oil Board, Kuala Lumpur, Malaysia: 420-431.

Guan Z and Eichler J. 2011. Liquid chromatography/tandem mass spectrometry of dolichols and polyprenols, lipid sugar carriers across evolution. Biochim Biophys Acta 1811(11): 800-806.

Hushiarian R, Nor AY, Sabo W.D. 2013. Detection and control of Ganoderma boninense: Strategies and perspectives. SpringerPlus2:555.

Mohammed CL, Rimbawanto A, Page DE. 2014. Management of basidiomycete root-and stem-rot diseases in oil palm, rubber and tropical hardwood plantation crops. Forest Pathol 44(6):428-446.

Morel A, Friedman R, Tulloch DJ, Caldecott B. 2016. Stranded assets in Palm Oil Production: A case study of Indonesia. Sustainable Finance Programme, SSEE, University of Oxford, Working Paper, July 2016.

Muniroh MS, Sariah M, Zainal Abidin MA, Lima N, Paterson RRM. 2014. Rapid detection of Ganoderma-infected oil palms by microwave ergosterol extraction with HPLC and TLC. J Microbiol Methods 100: 143-147.

Penuelas J, Munne-Bosch S. 2005. Isoprenoids: an evolutionary pool for photoprotection. Trends Plant Sci 10: 166-169.

Sagami H, Kurisaki A, Ogura K, and Chojnacki T. 1992. Separation of dolichol from dehydrodolichol by asimple two-plate hin-layer chromatography. J Lipid Res 33:1857-1862.

Schneider CA, Rasband WS, Eliceiri KW. 1992. NIH Image to ImageJ: 25 years of image analysis. Nat. Methods 9: 671-675.

Skorupińska-Tudek S, Bienkowski T, Olszowska O, Furmanowa M,Chojnacki T, Danikiewicz W,Swiezewska E. 2003.Divergent pattern of polyprenols and dolichols in differentorgans in Coluria geoides. Lipids38: 981-991.

Strzałka, Szymańska R, Świeżewska E, Skorupinska-Tudek K, Suwalsky M. 2009. Tocochromanols, plastoquinone and polyprenolsin selected plant species from Chilean patagoniaKazimierz. Acta Biol Cracov (Bot) 51: 39-44.

Sun F, Cai Z, Chaudhary MI, Xiao P, Cheng Y. 2010. Distribution of the triterpenoid saponins and chemotaxonomy of the genus Clematis L. by high-performance liquid chromatography-mass spectrometry. Biochem Syst Ecol 38: 1018-1025.

Swiezewska E, Sasak W, Mankowski T, Jankowski W, Vogtman T, Krajewska I, Hertel J, Skoczylas E, Chojnacki T. 1994. The search for plant polyprenols. Acta Biochim Pol 41: 221-260.

Tateyama S, Wititsuwannakul R, Wititsuwannakul D, Sagami H, Ogura K. 1999. Dolichols of rubber plant, ginkgo and pine. Phytochemistry 51: $11-15$

Tee SS, Tan YC, Faridah A, Meilina OA, Ho CL. 2013. Transcriptome of oil palm (Elaeis guineensis Jacq.) roots treated with Ganoderma boninense. Tree Genet. Genomes 9: 377-386

USDA. 2017. Indonesia and product annual report 2017. USDA Foreign Foreign Agricultural Service.

Zhang H, Ohyama K, Boudet J, Chen Z, Yang J, Zhang M, Muranaka T, Maurel C, Zhu JK, Gong Z. 2008. Dolichol biosynthesis and its effects on the unfolded protein response and abiotic stress resistance in Arabidopsis. Plant Cell 20:1879-1898. 